\title{
On the Application-oriented Talents' Cultivation at Undergraduate Level of Higher Education
}

\author{
Ke-Ke LIU \\ University of Jinan, Shandong, China 250022 \\ dp_liukk@ujn.edu.cn
}

Keywords: Higher Education; Undergraduate Level; Application-oriented; Talents Cultivating.

\begin{abstract}
From the perspective of application-oriented talents' cultivation at undergraduate level of higher education, the paper describes the connotation, proposes the approach and outlines the general view of cultivating application-oriented talents at undergraduate level of higher education.

According to the data released by the Ministry of Education in 2011, the total numbers of full-time undergraduate institutes in mainland China is 792, among which there are over 430 colleges and 350 universities. Undergraduate education is the foundation of higher education in China. Except for a few universities and colleges are research-based among 985 Higher Educational Institutes, and no matter teaching based or teaching-research based universities and colleges, most of the nearly 800 undergraduate level institutes in mainland China are application-oriented to train their students for the main battlefield of the economic development of our country which has important strategic significance to promote and realize our country to be more powerful in the field of human resource. This paper discusses a number of issues of application-oriented talents' cultivation at undergraduate level of higher education.
\end{abstract}

\section{The Connotation of Application-oriented Talents' Cultivation}

What is to cultivate application-oriented talent at undergraduate level? As I think, the distinction and boundary should be clarified among elite and academic based universities, career and technology based institutes and application-oriented universities and colleges. If the traditional elite and academic based universities train their students to be more useful, and student of career and technology based institutes is to be an artisan, then what application-oriented universities and colleges cultivate is to help their students to be talents. John S. Brubacher pointed out in his famous book On the Philosophy of Higher Education that Higher Learning is the logic origin of Higher Education Research. "Regardless of what type of its political, economic or religious system, a larger scale and modern society needs to establish an institute to pass esoteric knowledge, analysis and critique existing knowledge and explore new areas of science. In other words, those who need people to rationally analysis, identify and elaborate or concern, there will be a university." [1] What John S. Brubacher describes here is the cultivation of traditional elite-based and academic-based talents. But the logic origin of applicable-oriented talents' cultivation is the professional and applicable education which means the applicable-oriented undergraduate education is the professional and applicable education that bases on the general education. And starting from the logic origin, the core conception of applicable-oriented undergraduate education will be reached through intermediate concepts such as laws and principles of professional applied education etc. And then the logic end will be realized which is the target, cultivating model and realizing approaches of applicable-oriented undergraduate education.[2]

According to the International Standard Classification of Education (ISCED) revised by the UNESCO in1997, there are virtual differences on training orientation and function between subject-based professional education and applicable-oriented education though they both belong to the general higher education of 5A Level. Subject-based professional education is one of the 5A1 types, focusing on classification by discipline and generally preparing for research. Applicable-oriented professional education belongs to 5A2 type, focusing on classification by 
industry and which is the professional education for the requirements of hi-tech. Sequentially, Applicable-oriented professional education is the second type of professional applied education (5A2) which is between subject-based (5A1) and career-based (5B) education. This kind of education is industry-dominated; being professional is the main line of its nature; being applicable-oriented is the main body of its type; being teaching-based is the mainstream of its levels; and being practical is the main carrier of its mode. However, applicable-oriented professional education and the education of general university which focus on subject-based education are heterojunction isotype. It means, on its nature is the applicable-oriented professional education which is the undergraduate level that built on the general education, and its characteristic is to set out the majors that combines subjects with industries, then training advanced, professional and applicable talents for the first-line of the society.

National Education Reform and Development of Long-term Planning Programs (2010-2020) indicates that the colleges and universities, should optimize the structures and achieve the own characteristics, and meet the needs of the national and regional economic and social development establish a dynamic adjustment mechanism, to optimize the structure of higher education constantly. Optimizing the disciplines' major, types and hierarchical structures, then promote the cross and integration of multi-disciplines. Focus on the cultivating scale of applicable-oriented, compound and technical talents. To promote universities and colleges have their own features. Establish the classification system of higher education to practice the classified managements.

\section{The ways of application-based talents' cultivation}

\section{To construct and optimize major structure, teaching contents and curriculum}

Application-oriented undergraduate colleges and universities should initiatively integrate the education with economic and social development closely, and integrate the cultivation with employment closely. To further optimize the structure of major according to the development of economy and society, the stimulation of domestic demand, the need for industrial restructuring, and the change of job requirements. The colleges and universities should exploit the advantages to the full and condense their own features; strengthen the construction of brand and characteristic specialty; improve the level of major constructing. To adjust and transform the long-term majors which are low employment rate. To strengthen the argumentation work of new majors, foster new growth of the major, establish and perfect the system of majors' evaluation. Application-oriented undergraduate colleges and universities should adhere to the coordinated development of the knowledge, ability and quality, deepen the reform of the teaching contents, curriculum system and teaching methods and so on, and to realize the transformation of paying more attention to the capacity and quality training which is just focus on knowledge now. According to the needs of the development of society, economy, and talent market, to build a curriculum system which is combined by core courses and elective courses and conducive to integration of cross-curricular interests. Vigorously promote the reform of teaching methods and advocated heuristic, discussion, inquiry, participatory teaching and learning methods, focusing on individualized. Advocate the teaching model which is integrated by task-driven, project-oriented, and "to teach, to learn, to do". Promote the majors' construction and adjustment, further adjustments to the layout and structure of the major (field) for the development of economy and society. Build evaluation mechanisms for major construction; carry out the pilot work of verification and evaluation of majors. Reinforce the major construction which formed by colleges and enterprises build; Enhance Classified guidance of major construction, and create the major's advantage, brand and features to improve the level of the major construction. 


\section{Reforming the credit system as the grasp, to promote the development of student personality and all-round development.}

Reform the management system and operation mechanism, reduce the proportion of compulsive course and increase elective courses, to reduce the teaching hours of classroom lectures, to increase students' independent learning time and space, to broaden the students' knowledge, enhance students' interest and motivation for learning, perfect students' knowledge structure, and promote the development of students' personality. Application-oriented undergraduate colleges and universities should actively create conditions to increase curriculum resources and more high-quality courses which adapt to the needs of society and improve students' employability. Actively explore intercollegiate credit recognition and promote the management system and operational mechanism of the cooperation of inter-college teaching, so that more students can share high quality educational resources. In accordance with the general requirements of "talent-targeted, quality-centered, demand-oriented, personality development respected, and training-shunted" in the reform of education and teaching, to deepen the credit system reform and perfect shunted training to provide students with more opportunities of independent choices and more rooms for development. Construct and perfect the combination of to be professional and broad, be compatible with arts and science which conducive to promoting the curriculum system of student knowledge, ability, and quality improving comprehensively. Push forward the reform of the education and teaching methods to encourage discussion-based, heuristics-based and inquiry-based teaching methods. Advancing the reform of the examination methods, in assessment mode, gradually transform summative assessment to formative evaluation which concerned about how students learn. And the purpose and focus of the exam should be positioned to guide students to attach importance to the daily learning, willing to think and innovative capacity improving.

\section{To deepen the reform of the mode, improve the social adaptability of talents' cultivation.}

Application-oriented undergraduate colleges and universities should based on their own position, actively explore the diverse training model, establish and perfect the new training mechanism which is according to the needs of society, and participated by industry and enterprises. Application-oriented undergraduate colleges and universities should rely on the credit system to actively promote segmented training model, which is low-grade could organize the teaching by discipline or specialty categories, and the higher grades accords to the needs of the community and the personal hobby by students, then study relevant major and make major field clearly. Graduates are encouraged to extend 1-2 years to pursue a minor and a degree. Regard engineering as an important entry point to reform the talents training mode, and actively implement the diverse training models such as "talent cultivation according to the orders" and "working and learning alternation" etc. The reform of teaching approaches and methods is the difficulty point of the reform of talents' training mode. To reform the traditional closed and fusion teaching mode, strongly advocated heuristic, inquiry, discussion, and participatory based teaching and effectively change the teaching situation which is re-taught and ignore interaction, re-teaching and ignore educating people, and to create an open, collaborative, independent and inquiry learning atmosphere.

Play the leading role of teachers and main role of students, and to establish the concept of "effective teaching". Focus on the combination of learning and thinking, guide students learning independently and explore freely. Improve the quality of classroom teaching and its efficiency. Establish the concept of "team teaching" to encourage teachers to adopt in-class and group discussion, student statements and other forms of organization of teaching, so that students could participate in the teaching process to improve their problems analysis and solving abilities. Cooperation among teachers should be established; teaching interaction and teaching benefits teachers as well as students should be organized; a variety of effective learning methods between students should be formed. 


\section{Enhance the practice teaching and improve the students' practical skills and abilities.}

Application-oriented undergraduate colleges and universities should reinforce the reform of practice teaching and build a scientific system of practice teaching. Increase funding of practice teaching, and strengthen the construction of experiment, training and practice base. Further enhance the management and guidance of practice teaching, and actively organize internship practice and professional training which to promote employment is the purpose, ensure the implementation of graduates' internship and practice activities, and enhance the adaptability of graduates in jobs. Encourage and support students to participate actively in the activities of the extracurricular learning, technological innovation and skills competition, highlighting training and cultivation of the students' vocational skills and practical ability. Strengthen the management of practical training and carry out productive training actively. Reinforce the constructing of and reform practice teaching. Put forward the teaching mode which is cooperated by industry, college and institute and try out the mode of "working and learning alternation". Build a practice teaching platform for engineering innovation ability and social practice ability training, and an innovative training, industrial cognitive and exemplary practice base. Construct an open practice teaching system which will open to form new major, courses and laboratories. According to the requirements of different disciplines of practice teaching, to reform methods and means, improve the practical teaching system. To perfect a full range of teaching quality and the monitoring system, establish a long-term mechanism to guarantee the quality of talents cultivation. And gradually form a new mode of application-oriented talents' cultivation through reform.

\section{Enhance the team of teaching staffs, and put forward their leading roles in talents cultivation.}

Application-oriented undergraduate colleges and universities should strengthen the construction of teachers as a strategic task of the development of the college or university, effectively optimize the overall structure of teachers, and enhance practical teaching ability and overall quality of teachers. To guide teachers to keep abreast of the study of the development of society and economy and the needs of talents, reform teaching content on purpose and improve teaching methods, to form the educational reform mechanism that teaching with the latest academic achievements, and teaching contents are enriched and updated timely. Enhance the build of teaching team, and give full play to the leading role of the teachers' teaching. Lectures for diploma and bachelor students should be oriented as basic requirements for professor, associate professor. Strengthen the cultivation of young teachers and improve their teaching ability. To further strengthen the construction of the team of "theory and practice integrated" and "double qualified" teachers, and the proportion of "double qualified" teachers in basic courses and specialized courses need to meet certain requirements. Application-oriented undergraduate colleges and universities should also gradually introduce and cultivate a group of teachers with practical experiences. Strengthen teachers' occupation ideals, ethics education, enhance the sense of responsibility and mission of the teachers' teaching and educating, to guide teachers be loyal to the education, love their jobs and work hard and care for students, infect and educate students with charm of personality and knowledge, and to be the guidance and leader for student healthy growth.

\section{Reference}

[1] Brubacher, J. S. (1993). On the Philosophy of (C. X. Wang, Trans.). Zhengjiang: Zhejiang Education Publishing House. (Original work published 1977)

[2] Pan, M. Y. (1999). On the Issues of Construction of Higher Education Discipline. Journal of Higher Education, 2, 1-6. 